\title{
NARRATING TRAUMA IN LITERATURE: SORHA SANJHHARU
}

\author{
Badri Prasad Pokharel ${ }^{*}$ \\ Rita Majgayna
}

\begin{abstract}
The ten years of conflict that changed the political, economic, and cultural landscapes of our country. This period has been the topic of study for the researchers or scholars who want to bring out the facts about the people either involved in conflict from either side. Ordinary civilians did not notice things in depth when the insurgency was at climax and left the Nepali society in dilapidated the life of condition. Among many notable writers who penned about it, Govind Bartaman has depicted some vulnerable people who were undergoing with crippled life from both warring groups. Narrating their pangs he has forwarded the indelible horrendous memory in the form of trauma of these people who are still in the traumas. The atrocities being narrated in the book are very traumatic but the form of narrative has appeased the pains of the traumatized and an appeal to adjust with the perpetrators.
\end{abstract}

Key Words: atrocities, perpetrators, horrendous, pangs, memory, rupture, exodus, impunity, trauma.

\section{BACKGROUND}

The Maoist insurgency which erupted a rupture in Nepali diasporas for about ten years causing a massive destruction accounting for about the lives of more than thirteen thousand people more ordinary citizens than those of warring combatants, that ensued many to leave the houses and be refugees in their own country. The unending conflict between the state security force and the then Communist party of Nepal CPN (Maoist) along with its military using (the People's Liberation Army- PLA) under the leadership of Chairman Prachanda has not only proved the inefficacy of the Nepali state in curbing the challenge but also exposed the institutional fragility of the state in coping with disorder with rising cost of conflict. As the violent conflict intensified the enormity of cost as a premium of economic cost of violence, the human and social costs as well as the psychological trauma of the people- mostly nonaligned civilians crippled by the threats of both warring combatants, can never be properly assessed. The rising death tolls, torture, abductions, mass massacre caused by both warring groups induced severe human right

Mr. Pokharel is Lecturer in English at Bhaktapur Multiple Campus, T.U., Bhaktapur, Nepal and Mrs. Majgayna is Lecturer at Kathmandu Engineering College, Kalamati, Nepal 
violation of the citizenry. The government was losing administrative control of territories even in some districts surrounding the Kathmandu valley only with its weak and symbolic presence in the district headquarters. The horrendous level of violence leading to disintegrating civil disorder has contributed to social chaos, security impunity, devastating economic statusthat was all leading Nepal to a failure state which apparently occurred with the collapse of the state authority. "A military stalemate, whereby neither side can produce a victory, has been established, and chronic guerilla warfare prevails. The Maoist presents their goals as a 'remote and luminous horizon' or 'a mountain' that one endeavors to climb towards its unreachable top" (Marrie, 2000). However, the violence had disrupted the social fabric: dislocation and mass exodus from their domiciles was getting worse, the violent conflict was turning into a war, losses of agriculture production, declining industrial outputs and the excesses committed by both groups were all traumatic for the survivors and the for those who went through this period.

The political platform staged by the political parties' characters has enticed many prolific writers to create literary creations in different forms, for example, fiction i.e. Chhapamarko Chhoro, Sakas etc., memoir such as. Das Barse Janayudhaka Dobharu, Chhapamar Yuwatiko Diary, Sorha Sanjhharu, analytical writings i.e. A Kingdom Under the Seige: Nepal's Maoist Insurgency 1996 - 2004 by Deepak Thapa and Bandita Rayamajhi, Himalayan People's War: Nepal's Maoist Rebellion by Michael Hutt etc. These writings evoke the concept of 'trauma rendition' (Acharya, 2011)- an account of narrative which shows traumatic experience in Nepal that differs in its "magnitude, motives and the nature of perpetration and victimhood from these experiences" (Ibid). This paper tries to elaborate the trauma caused by Maoist insurgency in some people living in Western Nepal under the threat of both warring militants who were inclined to make their life battered and traumatized.

\section{THE CORPUS OF STUDY}

Govind Bartaman's Sorha Sanjhharu (2004), a remarkable account of a journey of some notable litterateurs including the writer himself, well known satirist and writer Khagendra Sangraula, and Suresh Dhakal, has brought out some indelible facts that happened during the horrendous Maoist insurgency which crippled the hinterland of western part of the country. Describing the nature and subject, Bartaman says, "I wrote what I endured during the journey for sixteen days encountering the conflict-struck survivors of the insurgency either from the hands of government forces or rebels" (Bartaman, 2004). Elucidating the traumatic facts that the travelers went through this journey, trauma in these people is presented as a "shock encounter with brutality or death or as Cathy Curuth puts it, as an overwhelming experience of sudden or catastrophic events, in which the 
response to the event occurs in the often delayed and uncontrolled repetitive occurrence of hallucinations and other intrusive phenomena" (Edkin, 2006). Characters or people like Bandana from Dang, Yashodha from Baglung, Sabina from Rolpa, Bhagundatta from Hasanpur etc. whom they met told them the painful experience how they lost their dear ones and enduring the traumatic grief even after a long a time.

\section{TRAUMA PROCESS}

Different scholars like Jenny Edkins, Cathy Curuth, Neil C. Hunt, Robert Brain Wall and many others have elaborated Trauma and it has been used in literature from different perspectives. But on the whole, they agree that trauma is clearly disruptive of settled stories and after a traumatic events, the situation moves quickly to close down any openings which are produced by putting in place as fast as possible a linear narrations of the originates. "Traumatic memory lies outside verbal- semantic linguistic representation and involves bodily skills, habits, reflection and classically conditioned responses. Whether through repression, dissociation or neurological shutdown or the impossibility of representing horrific events, the trauma is not available to consciousness or speech. The experience of trauma, thus becomes fixed or frozen in tissue" (Fierke, 2006). Here, memory or endeavors for forgetting is closely related to trauma. "Traumatic memory is an area where we can integrate work across different approaches in psychology, including biological, cognitive, social and psychodynamic perspectives" (Hunt, 2004). Using the idea of Hunt, Fierke, Bell etc. the paper appraises the nature of trauma as seen in Bartaman and the people whom he encountered during his journey. The analysis examines contextual and textual elements. Trauma has inflected him as violent events in his journey while meeting these traumatized people and listening their painful experience witnessing how their dear one got killed, kidnapped and severely tortured. Proximity avails him even the catastrophic conditions- emergency period, the royal massacre, intensified Maoist insurgency, short term armistice etc. and the sixteen evenings and survivors of these conditions "possessed by nostalgia for an age now irrevocably past, we revere its relics and indulge in magic rituals that are supposed to keep it alive" (Bell, 2006) and they remained obsessed by a cult of memory which remains in them and haunts in them as long as they remain survived.

\section{NARRATING TRAUMA}

After trauma occurs, the life and world of the victims will be divided into before and after the events, only memory remains to transfer the experience into the form of narratives either in fictional or non-fictional forms. "When the event is over, the post traumatic period becomes relatively distorted with the backdrop of the trauma continuously looming into the present. When the survivors of trauma come in and tell their stories they are 
in the process of creating wholeness from the destruction they have experienced" (Wall, 2008). Sharing traumatic grieves to the listeners either known or unknown would definitely listen the pain and they could feel relief and their life experience can be formed into the narrative either fictionally or as real as in the form of memoir. "The narration of experience is not only very widespread, it does appear to be essential for the health and that health gains can be made as a result of such narration" (Hunt, 2004). Narrating pain to others and listening the same from others shedding tears and crying may help gain solace in mind. As a result, the traumatized feel relief and the narration of such traumas may help gain a literary form- narrative. "People need to make meaningful sense of their experiences through the use of language and stories. This relationship between narrative, self and identity is central to our understanding of response to trauma, and links with social construction that help to build notions of self and identity" (Ibid). This way memory can be reconstructed in accordance with their theories of self - the personal views that would create the narratives. Thus, narrating pains and suffering is key to understanding the life and events happened in every stage. Narrative is a way of making meaning of our experiences so that readers or listeners would be able to grow from them.

\section{NARRATING TRAUMA IN SORHA SANJHHARU}

Recounting the experience through the formal medium of plot, fiction or spectacle let us repeat the post forward and this way, the act of repetition allows for a certain kind of pleasure or release the pain they have. "In the play of narrative recreations we are invited to revisit our lives- through the actions and personas to others- so as to live them otherwise. We discover a way to give a future to the past" (Kearney, 2007). Anyway, narrative pain is to revisit the past and to lead future ahead. The travelers'- Bartaman, Sangraula, Dhakal- encounter with Bandana and the narration of her pain the brutal death of her uncle Krishna Sen Ichchhuk in police custody stunned them. However, her resilience with the present condition- her father passes away, her mother's making an elopement to someone, the upbringing of her younger sisters, caring them playing the role of mother, cultivating the land to feed them as a father and her mental preparedness to face any catastrophes are all elucidated in the form of narrative that may help her residue the pain she's undergoing. Hasanpur's Bhagundatta Chaudhari's narration of his son's murder in the police custody is traumatic. A sixty years old father who knows that his son Binod Chaudhari, a Maoist cadre is no more but the incredible memory of his eldest son ever lets him feel that he is no more. He recounts him "I don't feel he is no more and killed; I still hope he is alive" (Bartaman, 2004). Expatiating his present condition, he further narrates, "Our family is of 18 members. Husbandry is not sufficient. Seven children go to school. No one from any parties, human right activists or social workers has ever helped 
us. It is very painful to endure the pain of my son's death and looking after all of them is another problem." (Ibid) Trauma narrated in this text through the people shows the ten years of Maoist insurgency was definitely unbearable and the people who went through this period only can narrate it from the heart to let other know it. The stories told by these people about their sufferings and pains detail the trauma to elucidate that the state or the rebel is irresponsible for the cause of such destruction and innocent people as traumatized became victims of the war. Spoken through these people Bartaman is able to highlight atrocities of both the government and the Maoist. The days and nights they spent in Rolpa waiting for the permission of the Maoists to let them enter the area is an example of the area under the control of the rebels and it seems there were two governments to rule over the denizens. Their meeting with comrade Saddham, a lean and thin in loose ragged half pant with high volume of speech to dominate over the words and control the freedom of people listening to him is inclined to show his authority. The failure to go ahead as they didn't get permission, gave them an opportunity to meet school children like Sabina, Ramesh etc. crippled by both warring groups. The narration of their painful experience made them realize the country's situation and the people in the atrocities of force and threat. Telling the painful stories in a sense "can be really received by the other person without causing the listener to be overwhelmed and to withdraw" (Wall, 2008). The listeners, here, Bartaman and his colleague were really overwhelmed and readily convinced with the pathos they were undergoing with. Another sabotage the rebel caused was the blaze of three buildings of human right office and schools, only because those offices did not speak in their favor. This office was located in Tikapur and the survivor of this event, Sunil Mishra was quoted saying "This is the heap of ashes of books, there was our library. Here were the books worth of seven lakhs. Almost all these books were about human right, development, national, international communist movements as well as literature, philosophy, history etc. All these books were burnt down and are lying on the ground as ashes" (Bartaman, 2004). Sunilji's memory is shadowed and he couldn't remember all, perhaps he is inclined to forget this traumatic event. Remembering and narrating this, he wouldn't get anything compensated; rather he may feel relief in his trauma. Tuknath Sharma, a health worker, abducted by security personnel and tortured severely in the barrack narrates his trauma, “'Don't talk more', one soldier chided. They made me walk carrying ten kilos of ammunition on my back for five hours to Kushma. They asked me many questions and mentally tortured me alleging my involvement with the rebels. Then I was kept in the custody of district police" (Ibid). Besides, VDC secretaries, local development offices, survivors of policemen's family, etc. were all to narrate their traumatic experience to them so as to "transform story into a narrative that is healing for the patient and beneficial to the listener - an empathic listener" (Wall, 
2008). Empathy is concerned to allow the listener to look and not turn away from the motifs of the storyteller.

\section{CONCLUSION}

From the discussion above, the conclusions could be: one, the analysis of this text which renders trauma of Maoist insurgency, and another it draws the attention of the scholars to opt for an approach to resort to interdisciplinary way to form alternatives for further studies and the narrative related to this insurgency is a fertile field of study that is waiting for more methodological innovation. Reading the rebellion through literature - memoir or travelogue with the help of trauma theorist Wall, Edkin, Hunt, Kearney would be one way to understand the situation. From this it is clear that narrating trauma with the method mentioned above will facilitate to reconstruct the text.

\section{WORKS CITED}

Acharya, K. (2011). "Trauma of Maoist Insurgency in Literature: Reading Palpasa Café, Forget Kathmandu and Chhapamarko Chhoro." Bodhi: An Interdisciplinary Journal. Dhulikhel: Kathamandu University, Vol. 5, No. 80-111.

Bartaman, G, (2004). Sorha Sanjhharu. Kathmandu: Printhouse.

Bell, D. (2006). "Introduction, Memory, Trauma and World Politics." Memory, Trauma and World Politics, Reflection on the Relationship between Past and Present. New York: Palgrave MacMillan, No.1-32.

Edkins, J. (2006). "Remembering Relationality: Trauma Time and Politics." Memory, Trauma and World Politics, Reflection on the Relationship between Past and Present. New York: Palgrave MacMillan, No.99115.

Fierke, K.M. (2006). "Bewitched by the Past: Social Memory, Trauma and International Relations." Memory, Trauma and World Politics, Reflection on the Relationship between Past and Present. New York: Palgrave MacMillan, No.116-134.

Hunt, Nigel O. (2004). Memory, War and Trauma. New York: Cambridge.

Kearney, R. (2007). "Narrative Pain: The Power of Catharsis." Paragraph. Vol. 30.1, No. 51-66.

Lecomte-Tilouine, M. (2006). "Kill One, He Becomes One Hundred Martyrdom as Generative Sacrifice in the Nepal People's War." Social Analysis. Vol. 50.1, No. 51-72.

Wall, R. B. (2008). "Healing from War and Trauma: Southeast Asians in the US; A Buddhist Perspective and the Harvard Program in Refugee Trauma." Human Architecture: Journal of the Sociology of Self-Knowledge. Vol. 3, No. 105-112. 